\title{
Kinetics study on dried Moringa oleiferaleaves during sun drying, multi commodity solar tunnel dryer drying and oven drying
}

\section{Sciendo}

\author{
Md. Suzauddula*, M Moeen Miah, NasimaAkterMukta, NajiaKamrul, Md. Bellal Hossain, \\ Department of Nutrition and Food Engineering, Daffodil International University, Dhaka-1207, \\ Bangladesh.
}

* To whom correspondence should be addressed. Email: suzauddula34-506@diu.edu.bd

Doi : 10.2478/mjhr-2019-0003

\begin{abstract}
Moringa oleifera leaves are familiar to all, but unknowing that this leaves contain quite a lot of nutrient value which are useful for human body function. This plant's leaves contain verities of antioxidant which inhabit \& fight against free radical to cell of human body for preventing cancer. Moringa leaves need to dry for use through diversified use. Storage and processing quality depend on better dry. The purpose of this research isto identifying and examined performance of different types of dryer to dry Moringa oleiferaleaves. For Moringa dried leaves apply three common type of dryer i.e. sun dryer, multi commodity solar tunnel dryer and oven dryer. This study was conducted to introducing \& used of Moringa oleifera leaves as ingredient of functional foods. Through this study the ration of time and moisture loss by several dryer are mentioned. Most of the dryer for temperature range $30^{\circ} \mathrm{C}$ to $70^{\circ} \mathrm{C}$. In MCST dryer found better in color and dried rate as compared others, highest moisture loss in happed in MCST dryer and total removal moisture $75 \%$. At each dryer $40 \mathrm{~g}$ sample was taken. Frequently after 2 hours the dryers were observed and the Moringaleaves (sample 1,2) were scatteredhomogenously into the baskets or salver. Moistnessreduction datawasnotedaftereach 2 hour breakswhile drying process running. The time and moisture contend will vary for based on the maturity of moringa leaves. In the closing moisture found at the final product was approximately $25 \%$ and total $17.50 \mathrm{~g}$. Optimum amount of moisture content increase shelf life, prevent loss of nutrition and protect form microbial spoilage.
\end{abstract}

Keywords: Kinetics study of moringa, drying effect of Moringa oleifera leaves, Moisture content of moringa leaves after sun, MCST and oven drying.

\section{Introduction}

The species of Moringa oleiferais under the family of Moringaceaeand in English it is called drumstick, which is under thegenus of Moringa and M. oleifera species which largely at Plantae kingdom. In India it has various names (Ramachandran et al., 1980) and it is identified as one of the most important Moringa leaves, as most of the part of Moringa trees are used in for food products and other beneficiary items. Moringa leaves are considered as significant source of ß-carotene, Ascorbic acid, CHON, Fe, P, Caand $\mathrm{P}$ are usually found at dried and crushed into powder and stored without conserving for months without defeat of nutritional values. Many specialists have leave comment on different nutrition features of moringa leaves(Fahey, 2005). The drying kinetics of food is not onlytough matter but alsonecessitatestrustworthysystem to guess drying charisma (Sharma et al., 2003). There is no organized methodology that is proved up to nowthru for receiving the sampleas ofMoringa oleifera(drumstick leaves).

Both tropical and sub-tropical area Moringa oleifera are grown-up. Moringa has been found as uncommonbush and easily digestible nutrient i.e. amino acid, vitamins, mineral andcarbohydrates are present which are trulycompulsory for human beings of very ages (Fahey, 2005). More than 100 reimbursements of our health and approximately 300 disease are able to control by consuming Moringa leaves. Some study found that over 90 nutrients, several antioxidants and entirely the eight essential 
amino acids are presence among it (Kumari et al., 2006). Our subjective process (drying) is the very antique $\&$ most used practice for preservation of fruits and other foods.

The food properties including discoloring, odor loss, textural changes, and nutritive value deviation through drying and also modify in carnalform and figure. Besides, there havetheresearch on drying negotiating at different dryers of Moringa leaves. Followed arethe intentions of it;

i) At this study moringa leaves were subjected to three different drying methods for identifying its several properties.

ii) Producing the drying curves with launch design (Guarte, 1996).Therefore, the current research aims to not only identify the drying behaviors ofleaves(drumstick leaves) but also detect an acceptable drying perfect to constructed kinetics of drying.

\section{Methods \&Materials:}

\section{1: Materials:}

Sample Fresh Moringa leaves were takenafter Moringa trees which grown at garden of Asulia (District Savar, Dhaka, Bangladesh,) campus of Daffodil International University and manual procedure was used to isolate the leaves by the stems and the initial toconcluding moisture contents of leaves were attained by the regular methodi.e. oven drying method (samples were subjected at preheated drying oven at $105^{\circ} \mathrm{C}$ for 1 hour with crucible and proper measurement) (Chan et al., 2009). The Moringa oleifera leaves (drumstick leaves) were 90\% (w.b)of the initial moisture content.

\section{2: List of equipment name which are used for drying purpose:}

\begin{tabular}{|l|l|}
\hline Sr. No & \multicolumn{1}{c|}{ Equipment } \\
\hline 1. & Analytical Balance scale \\
\hline 2. & Oven dryer \\
\hline 3. & MCST dryer \\
\hline 4. & Desiccator \\
\hline
\end{tabular}

For analyzing weight loss of the sample several digital analytical toolswere used. It's balance scale range (capacity 0-220g), this machine took time for stabilization time, $2-3$ seconds and readability $0.1 \mathrm{mg}$, repeatability $\mp 0.2 \mathrm{mg}$ for drying drumstick leaves used three kinds of dryer. Oven dryer,MCST dryer and Sun dryer during the drying time the sun temperature was between $30^{\circ} \mathrm{C}-35^{\circ} \mathrm{C}$, humidity $71-82 \%$ desiccators is used for safeguard chemicals which are hygroscopic or those respond with water of surrounding. It's a vacuum for prevent water vapor from incoming, and hold a desiccant so as tocaptivate any water vapor that does go in the compartment,

\section{3: Nutritive value of M. Oleifera:}

Leaves and others part of the plant contains rich medicinal values. It is now accounted as a worthy source of multiple identical commodity for the medicines against several diseases. The present issue is to concentrate on the nutritive values, physico-chemical assets, phyto-chemicals and pharmacological activities of M. Oleifera.

Leaves of moringa (drumstick) havenutritive value per $100 \mathrm{~g}$ and percentages of daily-recommended values are marked in brackets.

\begin{tabular}{|l|l|}
\hline Energy & $64 \mathrm{Kcal}(3 \%)$ \\
\hline Carbohydrates & $8.28 \%(6 \%)$ \\
\hline Protein & $9.40 \mathrm{~g}(17 \%)$ \\
\hline Total Fat & $1.40 \%(7 \%)$ \\
\hline Cholesterol & $0 \mathrm{mg}(0 \%)$ \\
\hline Dietary Fiber & $2.0 \mathrm{~g} \mathrm{(5 \% )}$ \\
\hline Vitamins: & \\
$\quad$ Folates & $40 \mathrm{ug}(10 \%)$ \\
Niacin & $2.220 \mathrm{mg}(14 \%)$ \\
\hline
\end{tabular}




\begin{tabular}{|l|l|}
\hline Pyridoxinel & $200 \mathrm{mg}(92 \%)$ \\
Riboflavin & $0.660 \mathrm{mg}(51 \%)$ \\
Thiamin & $0.257 \mathrm{mg}(21.5 \%)$ \\
Vitamin A & $7564 \mathrm{IU}(252 \%)$ \\
Vitamin C & $51.7 \mathrm{mg}(86 \%)$ \\
\hline Minerals & \\
Calcium & $185 \mathrm{mg}(18.5 \%)$ \\
Electrolytes Sodium & $9 \mathrm{mg}(0.5 \%)$ \\
Potassium & $337 \mathrm{mg}(7 \%)$ \\
Iron & $4.00 \mathrm{mg}(50 \%)$ \\
Magnesium & $147 \mathrm{mg}(37 \%)$ \\
Phosphorus & $112 \mathrm{mg}(20 \%)$ \\
Selenium & $0.9 \mathrm{ug}(1.5 \%)$ \\
Zinc & $0.60 \mathrm{mg}(5 \%)$ \\
\hline
\end{tabular}

(Source: USDA National Nutrient data base) 61 Page

In Moringa oleifera has contains a good source of major mineral calcium, phosphorous, magnesium, potassium and some major trace mineral also which is very important for health like zinc, iron, selenium and some vital vitamins.

\section{4: Drying experiments:}

\subsection{1: Preparation of Samples}

Moringa oleifera leaves which were harvested from stem by hand, sorted and weighed. Then a portion i.e. $40 \mathrm{~g}$ of Moringa oleifera leaves was taken into preheated drying oven at $105^{\circ} \mathrm{C}$ for 1 hour. After heat the sample was kept at desiccatorfor cool then it was weighted that found $10 \mathrm{gm}$. So $40 \mathrm{~g}-10 \mathrm{~g}=30 \mathrm{~g}(75 \%)$ moisture was present at sample.Then from the samples three equalportion of $80 \mathrm{~g}$ that each for the three criteria of drying (MCST drying, sun drying and ovendryer). To remove excess water each part was passed under a running tap and damped with a clean cloth.

2.4.1.1: Sun dryer (Esper, A., \&Mühlbauer, W. 1998):

Sample 1, first took towel dried fresh moringa leaves after remove excess water later washing and measured weight in balance meter, collect into 40 gsample and put the portion in a basket. For observe the moisture level checked out it in every 2 hours. After first 2 hours, leaves became dry and released 20 gfrom total weight and removal moisture $66.67 \%$ and net weight became only $20 \mathrm{~g}$, then after 8 hours finished time it loss more moisture in the result total weight of dry leaves 17.50 gand total removal moisture $75 \%$. Sample 2, of sun dryer: moringa leaves total weight is $17.91 \mathrm{~g}$ and total moisture 73.63 $\%$.

\subsubsection{2: MCST dryer:}

Sample 1, likewise sun dryer here sample 1 drying rate are same. So, result total weight of dry leaves 17.50 gand total removal moisture $75 \%$. Sample 2, and result total weight leaves 17.95 gand total removal moisture $73.5 \%$.

\subsubsection{3: Oven dryer:}

Sample 1, spread sample Moringa oleifera in a tray and put it in oven under $50^{\circ} \mathrm{C}$ temperature(Dev, S., et al., 2011). In first 2 hours leaves total weight 10 gand moisture loss $33.34 \%$. In final period total weight of sample became $17.56 \mathrm{~g}$, and total moisture 75\%. Sample 2, result total weights leaves 19.57 gand total removal moisture $68 \%$.flow chart for the preparation of samples is presented in figure 01 .

\subsubsection{4: Flow diagram:}




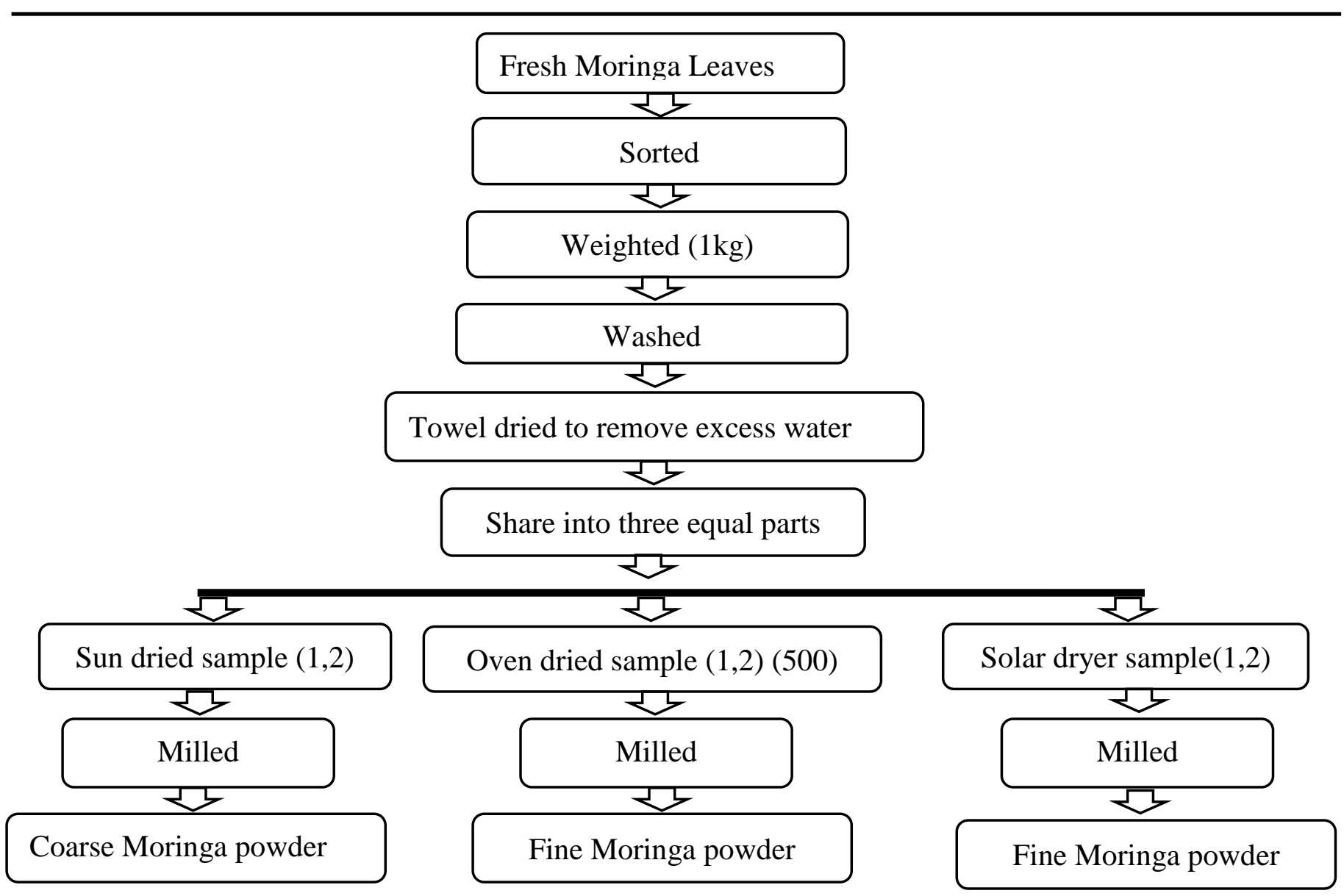

Figure 01: Flow diagram for the preparation of Moringa powder and paste.

\section{4: Results and discussion:}

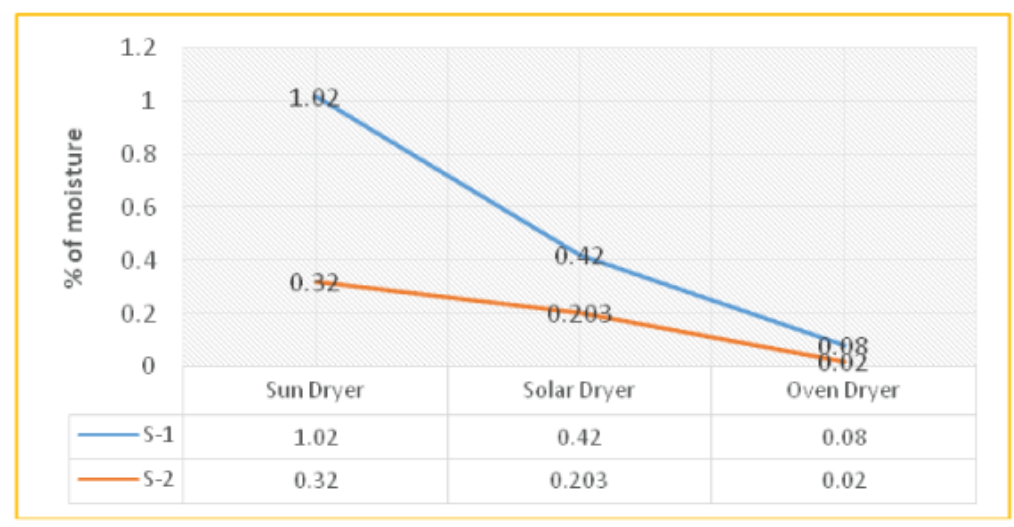

Figure 02: Graphical presentation of moisture content.

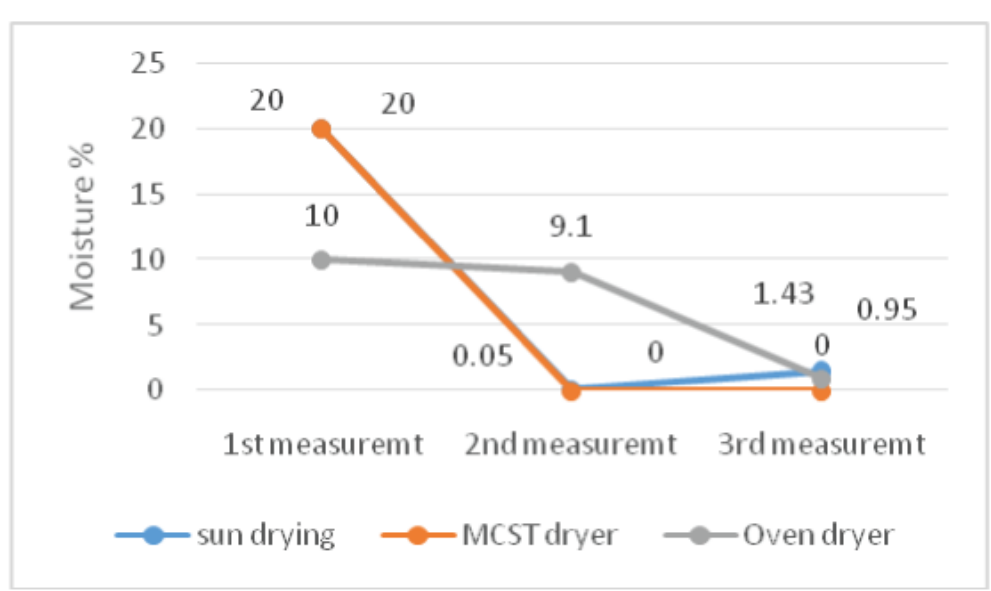

Figure 03: Moisture reduction carb in contrast of time. 
Mainly the flow of weight loss of leaves with increasing time, intensity of light at different dryer was observed. Prove curves ofdrying for Moringa leaves at sun drying, MCST dryer, \& oven dryer $\left(32,50\right.$ and $\left.60{ }^{\circ} \mathrm{C}\right)$ temperatures. The preliminary drying speed was from head to foot at all drying temperatures cause high heat was supplied at high temperature owing to which more moisture lossprocured. At oven drying $50{ }^{\circ} \mathrm{C}$ and MCST dryer $60{ }^{\circ} \mathrm{C}$ was maintained up to the exact moisture reading could be reduced by $25.12 \%$ and $75.00 \%$ in turn when associated to sun drying temperature $32^{\circ} \mathrm{C}$. The wholeperiodoccupied by Moringa leaves to touch moisture contents of $24.75,26.82$ and $33 \%$ at temperatures of 32,60 and $50^{\circ} \mathrm{C}$ were $2 \mathrm{~h}$ individually. The outcomes were more ensured that all three oven temperatures capable to decreased $\mathrm{M}$ leaves temperature less than that is auspicious for more processing. Moisture content of Sun Drying is less than MCST Drying system. Oven Drying Temperature is 65\% Moisture in 50 degree Celsius, and in all the dryers, the MCST dryer in Perth is fast enough to dry. 75\% Moisture in the MCST dryer. Curve itself is shown in every dryer good quality and good quality products. The study found that drying rate of solar and MCST dryer were similarly reduced with increasing time (hear 1st measurement have taken after 12 PM, 2nd measurement at 2 PM and 3rd measurement at 4.30 PM) have shown at figure 03 .

\subsection{Mathematical Calculation term of drying curves:}

\begin{tabular}{|c|c|c|c|c|c|c|c|c|c|c|}
\hline & \multirow{3}{*}{ Time } & \multicolumn{3}{|c|}{ Sun drying } & \multicolumn{3}{|c|}{ MCST dryer } & \multicolumn{3}{|c|}{ Oven dryer } \\
\hline & & \multicolumn{2}{|c|}{ Weight (g) } & \multirow{2}{*}{ Moisture } & \multicolumn{2}{|c|}{ Weight (g) } & \multirow{2}{*}{ Moisture } & \multicolumn{2}{|c|}{ Weight (g) } & \multirow{2}{*}{ Moisture } \\
\hline & & Starting & End & & Starting & End & & Starting & End & \\
\hline \multirow{4}{*}{ 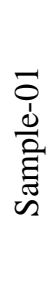 } & $\begin{array}{l}10 \mathrm{AM}-12 \\
\mathrm{PM}\end{array}$ & 40 & 20 & 20 & 40 & 20 & 20 & 40 & 30 & 10 \\
\hline & $1 \mathrm{PM}-2 \mathrm{PM}$ & 20 & 19.95 & 0.05 & 20 & 19.8 & 0.20 & 30 & 20.9 & 9.1 \\
\hline & $\begin{array}{l}2.30 \mathrm{PM}- \\
4.30 \mathrm{PM}\end{array}$ & 19.95 & 18.23 & 1.43 & 19.80 & 17.92 & 1.88 & 20.90 & 19.95 & 0.95 \\
\hline & $\begin{array}{l}10 \mathrm{AM}-12 \\
\mathrm{PM}\end{array}$ & 18.23 & 17.91 & 1.02 & 17.92 & 17.5 & 0.42 & 19.95 & 19.87 & 0.08 \\
\hline \multirow{4}{*}{  } & $\begin{array}{l}10 \mathrm{AM}-12 \\
\mathrm{PM}\end{array}$ & 40 & 20 & 20 & 40 & 20 & 20 & 40 & 33 & 7 \\
\hline & $1 \mathrm{PM}-2 \mathrm{PM}$ & 20 & 19.97 & 0.03 & 20 & 19.89 & 0.11 & 33 & 20.17 & 12.83 \\
\hline & $\begin{array}{l}2.30 \mathrm{PM}- \\
4.30 \mathrm{PM}\end{array}$ & 19.97 & 18.23 & 1.74 & 19.89 & 18.15 & 1.797 & 20.17 & 19.59 & 0.58 \\
\hline & $\begin{array}{l}10 \mathrm{AM}-12 \\
\mathrm{PM}\end{array}$ & 18.23 & 17.91 & 0.32 & 18.153 & 17.97 & 0.203 & 19.59 & 19.57 & 0.02 \\
\hline
\end{tabular}

Table 01: Moisture content of Moringa oleifera leaves in contrast of time.

\section{5: Conclusions:}

Sun dryer, MCST dryer \& oven dryer were used to drying Moringa oleiferaleaves. With increasing drying time the rate of existing moisture were reduceduninterruptedly. At the last time the moisture reduce at significantly. So could be possible to shorter drying time by increasing drying temperature. Dried MCST dryer was establishing to be the optimal in terms of energy effectiveness and maintainingsubjects (goods) quality. By the process of drying changes in the food properties including textural changes, discoloring, loss, aroma, and nutritive value as well and also vagaries in physical look and shape. In this study it was clearly observed that by using MCST dryer the optimum quality of moringa leaves during drying and storage stay better than other dryer. During starting time sun dry and MCST dryer have equal rate of drying but at last time the performance goes higher to MCST dryer where over dryer show low performance during $1^{\text {st }}$ and $2^{\text {nd }}$ measurement but not at last measurement.

\section{6: Conflict of Interest}

There is no conflict of interest

\section{7: References:}

1. Ramachandran, C., Peter, K.V.,Gopalakrishnan, P.K. 1980. Drumstick (Moringa oleifera): a multipurpose Indian vegetable. Economic Botany, 34(3), 276-283.

2. Fahey, J.W. 2005. Moringa oleifera: a review of the medical evidence for its nutritional, therapeutic, and prophylactic properties. Part 1. Trees for Life Journal, 1(5), 1-15. 
3. Kumari, P., Sharma, P., Srivastava, S., Srivastava, M.M. (2006). Bio sorption studies on shelled Moringa oleifera Lamarck seed powder: removal and recovery of arsenic from aqueous system. International Journal of Mineral Processing, 78(3), 131-139.

4. Guarte, R.C. 1996. Modelling the drying behavior of copra and development of a natural convection dryer for production of high quality copra in the Philippines. PhD Dissertation, Hohenheim, Stuttgart, Germany. 5. Chan, E.W.C., Lim, Y.Y., Wong, S.K., Lim, K.K., Tan, S.P., Lianto, F.S., Yong, M.Y. 2009. Effects of different drying methods on the antioxidant properties of leaves and tea of ginger species. Food chemistry, 113(1), 166-172.

6. Esper, A., Mühlbauer, W. 1998. Solar drying-an effective means of food preservation. Renewable Energy, 15(1-4), 95-100.

7. Dev, S.R.S., Geetha, P., Orsat, V., Gariépy, Y., Raghavan, G.S.V. 2011. Effects of microwave-assisted hot air drying and conventional hot air drying on the drying kinetics, color, rehydration, and volatiles of Moringa oleifera. Drying Technology, 29(12), 1452-1458.

8. Yaldiz, O., Ertekin, C., Uzun, H.I. 2001. Mathematical modeling of thin layer solar drying of sultana grapes. Energy, 26(5), 457-465.

9. Doymaz, I., Pala, M. 2002. Hot-air drying characteristics of red pepper. Journal of Food Engineering, 55(4), 331-335.

10. Doymaz, I. 2004. Drying kinetics of white mulberry. Journal of Food Engineering, 61(3), 341-346.

11. Makkar, H.A., Becker, K. 1996. Nutritional value and anti-nutritional components of whole and ethanol extracted Moringa oleifera leaves. Animal Feed Science and Technology, 63(1-4), 211-228. 